\title{
Adoption and Effectiveness Value of RFID Based Digital Recording System for Commercial and Rural Beef Cattle Farming
}

\author{
Bramada Putra ${ }^{1}$, Nurul Chamidah ${ }^{2}$, Siti Junaesih ${ }^{3}$, Abdul Matin ${ }^{4}$, Indria \\ Widyawan $^{5}$, Sodik Ihwan ${ }^{6}$ and Ali Agus ${ }^{7, *}$ \\ ${ }^{1}$ Faculty of Animal Science, Institut Pertanain Bogor, Bogor 16680 Indonesia \\ ${ }^{2}$ Faculty of Politic and Social Science, Universitas Muhammadiyah Cirebon, Jawa Barat 45611 Indonesia \\ ${ }^{3}$ Faculty of Accounting, STIE Tridharma, Bandung 40264 Indonesia \\ ${ }^{4}$ Grow Up Institute, Bojong Soang No 122, Dayeuhkolot, Bandung, 40257, Indonesia \\ ${ }^{5}$ Faculty of Sustainable Tourism, Universitas Padjadjaran, Bandung 40132 Indonesia \\ ${ }^{6}$ Buana Integrasi Solusi Infotama, Jl. Telekomunikasi No. 1 Dayeuhkolot, Bandung 40257 Indonesia \\ ${ }^{7}$ Faculty of Animal Science, Universitas Gadjah Mada, Yogyakarta 55281 Indonesia \\ *Corresponding author. Email: aliagus@ugm.ac.id
}

\begin{abstract}
One of the main challenges in livestock sector especially cattle farming in Indonesia which is very crucial is recording system for livestock production that can be valid. A simple way can be a solution for this challenge is used of RFID based digital recording system. This system is utilizing microchips in the RFID tags that are attached to each cattle, in addition to avoiding human error both in counting and recording, also eliminating the possibility of double data, because every single RFID Tag has a Unique-ID as the individual identity for each cattle. RFID based digital recording system was tried by comparing commercial beef cattle farming $(\mathrm{CF})$ and rural beef cattle farming (RF) at Lampung province of Indonesia. Cattle population that used for this research are 1.473 heads for CF and 992 heads for RF. The data that recorded is ear-tag number, breed, sex, body weight, and paddock with a remark when needed. The parameters compared of both farming are number of cattle that can be recorded per day and time required to record per head of cattle (second). Effectiveness value of this system on rural farming was learned through by comparing for each trial for first trial to fourteenth trials of time required to record per cattle. Data was analyzed by t-student test method. CF more adaptive and effective than RF for RFID based digital recording system. Number of cattle that can be recorded per day by CF was significantly higher $(199 \pm 100,70)$ than $\mathrm{RF}(63 \pm 33,51)$. Time required to record per head of cattle by $\mathrm{CF}$ was significantly shorter $(29,85 \pm 12,37)$ than $\operatorname{RF}(68,95 \pm 30,76)$. Time required to record per cattle was significantly reduce at Trial 1 (130.814), 2 (115.458), 3 (86.313), 8 (66.053), 9 (53.841), 11 (40.424), 14 (29.867). The last trial time required to record per cattle of RF was equal with CF. RFID based digital recording system for livestock was adaptable and effective for both of commercial beef cattle farming and rural beef cattle farming.
\end{abstract}

Keywords: RFID, digital recording system, commercial, rural, beef cattle farming.

\section{INTRODUCTION}

The main problem of the livestock industry in Indonesia which is very crucial is the absence of a standard livestock recording system that can be a valid reference to determine population development, productivity, reproductive status, distribution, level of livestock availability as well as mapping the potential and problems of national livestock. Common problems that occur in manual data collection, include data input errors due to errors in reading and recording, as well as the occurrence of duplicate data due to the absence of Unique-ID which is the identity of each cattle. A simple way can be done to anticipate this, by utilizing a microchip in the form of an RFID Tag that is attached to each cattle, in addition to avoiding the occurrence of human errors both during counting and recording, also 
eliminating the possibility of duplicate data, because each RFID Tag has a Unique-ID as identity of each cattle. The digital recording model using RFID can be implemented on national farms with various typological scenarios, both nationally and regionally, in livestock companies, livestock areas and smallholder farms. One of the centers of beef cattle farming in Indonesia is Lampung province. RFID based digital recording system was tried by comparing commercial beef cattle farming and rural beef cattle farming at Lampung province of Indonesia.

\section{MATERIAL AND METHODS}

\subsection{Material}

Cattle population that used for this research are 1.473 heads from three commercial beef cattle farming and 992 heads from rural beef cattle farming from smallholder farmer at Lampung Selatan. All livestock is given RFID Ear Tag which there is a RFID Micro chip that using TK4100/EM4205/EM4305 chip on frequency 134.2 kHz. RFID Reader and Digital Recording Software are using the product of PT. Buana Integrasi Solusi Infotama. RFID Reader is "Made in Indonesia" product that can read RFID Tag on frequency $134.2 \mathrm{kHz}$ using FDX$\mathrm{B} / \mathrm{HDX}$ protocol as described on ISO-11784/11785 standard and equipped with Micro-SD Card for storage media. The software is connected to digital animal scales for automatic weight recording, and connect to RFID Reader for automatic cattle identity recording, and use MariaDB for database server to save the data.

\subsection{Method}

\subsubsection{General}

The data that recorded is ear tag number, breed, sex, body weight, and paddock with a remark when needed. The parameters compared from both farming type are number of cattle that can be recorded per day and time required to record per head of cattle (second). Effectiveness value of this system on rural farming was learned through by comparing for each trial from first trial to fourteenth trials of time required to record per cattle.

\subsubsection{Statistic}

Table 1. Adoption value of RFID system

\begin{tabular}{|l|l|l|}
\hline & CF & RF \\
\hline Number of cattle that can be recorded per day & $199 \pm 100,70^{\mathrm{b}}$ & $63 \pm 33,51^{\mathrm{a}}$ \\
\hline Time required to record per head of cattle (second) & $29.85 \pm 12.37^{\mathrm{a}}$ & $68.95+30.76^{\mathrm{b}}$ \\
\hline
\end{tabular}

CF: commercial beef cattle farming

RF: rural beef cattle farming

Different superscript in the same row means significantly different $(\mathrm{P}<0.05)$

Table 2. Effectiveness value of RFID system

\begin{tabular}{|l|l|l|}
\hline Trial Repetition Number & Mean & Duncan Grouping \\
\hline Trial-1 (21-Feb-21) & $130.81 \pm 35.52$ & A \\
\hline Trial-2 (22-Feb-21) & $115.46 \pm 42.77$ & B \\
\hline Trial-3 (26-Feb-21) & $86.31 \pm 31.92$ & C \\
\hline Trial-4 (01-Mar-21) & $82.82 \pm 25.23$ & C \\
\hline Trial-5 (02-Mar-21) & $81.09 \pm 30.00$ & C \\
\hline Trial-6 (03-Mar-21) & $81.55 \pm 41.46$ & C \\
\hline Trial-7 (04-Mar-21) & $80.82+37.67$ & C \\
\hline Trial-8 (05-Mar-21) & $66.05+31.08$ & D \\
\hline Trial-9 (10-Apr-21) & $53.84 \pm 9.04$ & E \\
\hline Trial-10 (17-Apr-21) & $45.07 \pm 29.13$ & EF \\
\hline Trial-11 (18-Apr-21) & $40.42 \pm+14.39$ & FG \\
\hline Trial-12 (22-Apr-21) & $36.15 \pm 16.37$ & FG \\
\hline Trial-13 (28-Apr-21) & $35.07 \pm 11.13$ & FG \\
\hline Trial-14 (01-May-21) & $29.87 \pm 12.19$ & G \\
\hline
\end{tabular}


Number of cattle that can be recorded per day and time required to record per head of cattle were analyzed using the t-student test method. The model used to analyze was:

$$
t=\frac{\left(\bar{x}_{a}-\bar{x}_{b}\right)-\left(\bar{\mu}_{a}-\bar{\mu}_{b}\right)}{\sqrt{\frac{s_{a}^{2}}{n_{a}}+\frac{s_{b}^{2}}{n_{b}}}}
$$

Where $\bar{x}_{a}=$ a sample mean, $\bar{x}_{b}=\mathrm{b}$ sample mean, $\bar{\mu}_{a}=\mathrm{a}$ population mean, $\bar{\mu}_{b}=\mathrm{b}$ population mean, $s_{a}=\mathrm{a}$ standard deviation, $s_{b}=\mathrm{b}$ standard deviation, $n_{a}=\mathrm{a}$ sample amount, $n_{b}=\mathrm{b}$ sample amount. Significance was declared at $\mathrm{P}<0.05$.

Effectiveness value were analyzed by comparing for each trial for first trial to fourteenth trials of time required to record per cattle using Analysis of Variance with Completely Randomized Design. The model used to analyze was:

$\mathrm{Y}_{\mathrm{ij}}=\mu+\mathrm{P}_{\mathrm{i}}+\varepsilon_{\mathrm{ij}}$

Where $Y_{i j}=$ the value of the observation of the $i$ treatment and the $\mathrm{j}$ repetition, $\mu=$ median, $\mathrm{P}_{\mathrm{i}}=\mathrm{i}$ treatment effect, $\varepsilon_{\mathrm{ij}}=$ experiment error effect. Significance was declared at $\mathrm{P}<0.05$.

\section{RESULT AND DISCUSSION}

Adoption value of RFID system are presented in Table 1. Effectiveness value of RFID system are presented in Table 2. Number of cattle that can be recorded per day by commercial beef cattle farming was significantly higher $(199 \pm 100,70)$ than rural beef cattle farming $(63 \pm 33,51)$. Time required to record per head of cattle by commercial beef cattle farming was significantly shorter $(29,85 \pm 12,37)$ than rural beef cattle farming $(68,95 \pm 30,76)$. Adoption value of RFID system are higher for commercial beef cattle farming than rural beef cattle farming. This condition may occur due to routine training carried out by commercial beef cattle farming in the operation of the RFID system or it could be due to repetition RFID system using in commercial beef cattle farming which is more frequent than rural beef cattle farming. The effectiveness value test shown that the more often rural beef cattle farming repeats the use of the RFID system, it takes less time to record per head of livestock until the 14th test shows the time required to record per head of cattle is equal with commercial beef cattle farming. Repetition of the RFID system using until the 14th repetition takes 69 days with the average of repetition time interval is 5 days.

\section{AUTHORS' CONTRIBUTIONS}

Adoption value of RFID system at commercial beef cattle farming was higher than at rural beef cattle farming. Repetition of the RFID system using will increase the effectiveness value of RFID system implementation at rural beef cattle farming.

\section{REFERENCES}

[1] Adrion F, Kapun A, Holland EM, Staiger M, Löb P, Gallmann E. 2017. Novel approach to determine the influence of pig and cattle ears on the performance of passive UHF-RFID ear tags. Computers and Electronics in Agriculture. 140:168-179.

[2] Adrion F. 2018. Adaption and assessment of a UHF-RFID system for livestock management [Disertation]. [Stuttgart (Germany)]: University of Hohenheim.

[3] Feng J, Fu Z, Wang Z, Xu M, Zhang X. 2013. Development and evaluation on a RFID-based traceability system for cattle/beef quality safety in China. J Food Control. 31:314-325.

[4] Foster TP, Schweihofer JP, Grooms DL, Clarke RH, Buskirk DD. 2018. Comparison of beef traceability in serial and parallel fabrication systems using RFID and two-dimensional barcodes. J Transl. Anim. Sci. 2018.2:101-110.

[5] Hammer N, Adrion F, Staiger M, Holland E, Gallmann E, Jungbluth T. 2016. Comparison of different ultra-high-frequency transponder ear tags for simultaneous detection of cattle and pigs. J Livestock Science. 187:125-137.

[6] Hong-da W. 2012. Application of radio frequency identification (RFID) in dairy information management. J Northeast Agricultural University (Eng Ed). Vol.19 No.1: 78-81.

[7] Liang W, Cao J, Fan Y, Zhu K, Dai Q. 2015. Modeling and implementation of cattle/beef supply chain traceability using a distributed RFID-based framework in China. J Plos One. Oct 2: 1-17.

[8] Myerson, JM. 2007. RFID in the supply chain : a guide to selection and implementation. New York (US): Auerbach Publications.

[9] Roberts AJ, Wallace LE, Harbac M, Paterson JA. 2012. CASE STUDY: Retention and readability of radio frequency identification transponders in beef cows over a 5-year period. J The Professional Animal Scientist. 28: 221-226.

[10] Wahyuni PW. 2014. Rancang bangun timbangan dan pemanfaatan radio frequency identification untuk manajemen dan registrasi ternak [Skripsi]. [Surabaya (Indonesia)]: STIKOM Surabaya.

[11] Wibowo MC, Wahyuni PW, Mardiana IDGR, Rasmana ST. 2013. Sistem informasi dan registrasi ternak pada kelompok peternak kambing di Malang. Prosiding Seminar Nasional Teknologi Informasi dan Multimedia. Yogyakarta, 
19 Januari 2013. Yogyakarta (Indonesia): STMIK AMIKOM. hlm. 19-26.

[12] Williams LR, Fox DR, Hurley GJB, Swain DL. 2019. Use of radio frequency identification (RFID) technology to record grazing beef cattle water point use. J Computers and Electronics in Agriculture. 156:193-202.

[13] Wallace LE, Paterson JA, Clark R, Harbac M, Kellom A. 2008. Readibility of thirteen different radio frequency identification ear tags by three different multi-panel reader systems for use in beef cattle. J The Professional Animal Scientist. 24: 384-391. 